\title{
Differences In Selection Criteria Among Traditional Students, Adult Continuing Education Students And Graduate Students
}

Kurt Schimmel, D.B.A., Robert Morris University, USA

Mark Eschenfelder, Ph.D., Robert Morris University, USA

John Clark, Ph. D., Robert Morris University, USA

Gayle Marco, Ph.D., Robert Morris University, USA

Stanko Racic, Robert Morris University, USA

\begin{abstract}
This paper examines college selection cues and criteria differences among three important segments of students. These segments were traditional undergraduate students, adult continuing education students and graduate students. There were significant differences among the a-priori defined segments.
\end{abstract}

Keywords: College Selection Criteria, Marketing, Empirical Test, Consumer Behavior

\section{INTRODUCTION}

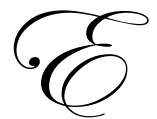

nrollments matter to colleges and universities. Enrollments directly and indirectly influence the financial resources available to higher education institutions. Enrollment is related to tuition revenue and the ability to attract other private and public funding. The market to attract students to particular colleges and universities has become more competitive (Brookes 2003; Kirp 2003; Tapp, Hicks \& Stone 2004). The increase in competition for new students has lead to increased interest by colleges and universities in marketing themselves to prospective students. Knowledge of the preferences of new and current students is useful to colleges and universities trying to maintain and/or grow enrollment. It allows an institution to target prospective students and segment based on the selection attributes increasing the marketing efficiency of the institution (Hooverstad, Lamb, \& Miller 1989).

Many colleges and universities offer a variety of degree programs aimed at different audiences. These audiences may place different values on the attributes of colleges and universities leading them to focus on different institutional characteristics as they make selection decisions. An institution that understands its attributes and the role they play in the selection of the institution by students can communicate more effectively and build a more positive brand image (Ivy 2001). They may also use this information in the strategic planning of the institution to allocate the school's resources in a manner that increases the return on investment through increased enrollment and tuition dollars.

This paper focuses on the selection criteria of different classifications (traditional undergraduate, graduate, nontraditional undergraduate (adult continuing education A.C.E.)) of students at a single university. This work complements the existing literature by relating selection criteria of a particular classification of student to assessments of the performance of the university by those students. Understanding the criteria used by different classifications of students selecting a college or university is useful in growing and/or maintaining enrollments by providing information that can be used to help attract and retain different types of students. 


\section{THE SELECTION PROCESS}

The college selection process has been described as a five stage process (Chapman 1986) first is pre-search behavior where the student starts to consider college and begins the cost benefit analysis of higher education. The second phase is the search process, the prospective student is active seeking and gathering information on specific colleges or universities. During this phase the prospective student seeks out comparative information about specific attributes they consider important. The third phase is the application decision, the student determines the schools they will apply to and the probability that they will be accepted by those institutions. The fourth phase is the choice decision, the student evaluates the expected utility of each of the schools to which the student has been accepted and selects the school which yields the highest expected utility. The final stage is matriculation, actually attending the chosen school. This paper focuses on the selection criteria (attributes) which are developed in the second phase and utilized in the third and fourth phases of the decision process.

\section{SELECTION CRITERIA}

In research that partially supported Chapman's theoretical model, Moogan, Baron and Bainbridge (2001) found the selection process to be a utility function. However, the weightings given to attributes changed from the third to the fourth phase in the selection process. Specifically, course offerings were important early in the decision process but became less important in the choice, location became more important in the choice phase. An institution's reputation was important through all phases of the college selection process.

The importance of strong academic offerings and reputation has been consistently supported as important selection criteria by other researchers (Krampf \& Heinlein 1981; Hooly \& Lynch 1981; Soutar \& Turner 2002; Donaldson \& McNicholas 2004). Other criteria have been found to be relevant in the selection process. These include: The attractiveness of the campus and the quality of the campus visit (Krampf \& Heinlein 1981) and the accreditation of the institution (Donaldson \& McNicholas 2004). The perception that attendance at the school will increase prospective students' job prospects was empirically supported by two studies (Donaldson \& McNicholas 2004 Soutar \& Turner 2002). Researchers have also noted the importance of quality of instruction in the selection process (Soutar \& Turner 2002). Location was an important criterion in several studies (Soutar \& Turner 2002; Donaldson \& McNicholas 2004; Hooly \& Lynch 1981) as was the recommendations of others (Krampf \& Heinlein 1981; Hooly \& Lynch 1981; Soutar \& Turner 2002). The facilities available to students on campus (Price, Matzdorf, Smith \& Agahi, 2003) was noted as playing a role in students' selection of an institution. Judson, James \& Aurand (2004) found the characteristics which attract male and female intercollegiate athletes to an institution differ. Males place more importance on athletic characteristics of a university than females while females are more concerned with academic characteristics than males. As this review indicates there is a developing body of literature exploring the college selection process, but no consistent set of attributes have been utilized across the studies. There have been some commonalities of attributes; however, the methodology in operationalizing the variables and testing importance has differed. This study should be viewed as an exploratory study that complements the existing literature by examining a comprehensive list of attributes that vary from the academic quality, to the location and physical attributes of the campus and testing for differences in the selection criteria of different groups of students.

\section{METHODOLOGY}

This paper examines the selection criteria of three types of students at a single four-year institution. The university with an enrollment of approximately 5,000 undergraduate and graduate students offers more than 30 undergraduate degree programs and 18 master and doctoral degree programs. The categories of students are traditional undergraduate, students entering higher education directly from high school; non-traditional undergraduate, adults seeking undergraduate degrees in accelerated formats with some online delivery of courses; and graduate, students pursuing master or doctoral degrees.

Data was collected using websurveyor, an online survey tool. Incoming students were sent an email asking for their participation. Two hundred and fifty seven incoming students out of 683 responded to the survey for a response rate of $37 \%$. The demographics of the respondents are in Table 1. 
Table 1

Demographics of The Respondents

\begin{tabular}{|l|c|c|}
\hline \multicolumn{1}{|c|}{ Variable } & Frequency & Percent \\
\hline Student Status & & 38.5 \\
\hline Traditional & 99 & 42.0 \\
\hline Graduate & 108 & 19.5 \\
\hline Adult Continuing Ed. & 50 & 42.2 \\
\hline Gender & & 57.8 \\
\hline Male & 108 & 13.1 \\
\hline Female & 148 & 30.4 \\
\hline Household Income & & 27.4 \\
\hline Under $\$ 20,000$ & 31 & 15.6 \\
\hline $20-40,000$ & 72 & 7.6 \\
\hline $40-60$ & 65 & 4.6 \\
\hline $60-80$ & 40 & \\
\hline $80-100$ & 18 & 92.9 \\
\hline 100 and up & 11 & 5.9 \\
\hline Ethnicity & & .8 \\
\hline Caucasian & 235 & .4 \\
\hline African American & 15 & \\
\hline Asian & 2 & \\
\hline Hispanic & 1 & \\
\hline Other & & \\
\hline \hline
\end{tabular}

\section{MEASURES}

The selection criteria were measured using 19 items. The items were measured on a six point scale anchored with the end points "totally Unimportant" and "exceptionally Important."

The selection criteria were assessed for underlying common dimensions using principle components factor analysis. A Varimax rotation was performed to examine the structure of the factors with an orthogonal rotation. The resulting factors were examined for internal consistency using Cronbach's alpha. The results of the factor analysis are presented in Table 3. The student respondents were classified using self identification as a traditional undergraduate student, adult and continuing education (ACE) student or graduate student.

The first factor was named "Academics" consisted of the following five variables: Accreditation of the school's programs; the presence of a specific major field of study; the reputation of the University; flexibility of the course offerings; and, the ability to specialize inside your major field of study. Academics has a Cronbachs alpha of .886. The second factor was named "campus life" was comprised of seven variables: Access to internships; the ability to live on campus; the ability to participate in intercollegiate athletics; the number of computers available for students; the ability to transfer credits; the school is a private school; and, financial aid packages. Campus life had a internal consistency of .819. The third factor was named "Speed / Convenience" it has an internal consistency of .799 and contained three variables: Eight week class formats; the ability to schedule evening classes; and, the speed of degree completion. The fourth factor was named "Location /Cost" and consisted of four variables: The location of the school is close to your home; the ability to commute to campus; the location of the school is close to where you work; and, tuition cost. Location/Cost's internal consistency was .741. The scales all have sufficient internal consistency to allow summation. New summated variables were created for each based on the factor analysis results. 
Table 2

Rotated Component Matrix (a)

\begin{tabular}{|c|c|c|c|c|}
\hline & \multicolumn{4}{|c|}{ Component } \\
\hline & Academics. & Campus Life & Speed/ Convenience & Location Cost \\
\hline & Alpha .886 & Alpha .819 & Alpha .799 & Alpha .741 \\
\hline Accreditation of the school's programs & .824 & & & \\
\hline $\begin{array}{l}\text { The presence of a specific major your } \\
\text { wanted to study }\end{array}$ & .813 & & & \\
\hline The reputation of the University & .725 & & & \\
\hline Flexibility of the course offerings & .718 & & & \\
\hline $\begin{array}{l}\text { The ability to specialize inside your } \\
\text { major field of study }\end{array}$ & .713 & & & \\
\hline Access to internships & & .786 & & \\
\hline The ability to live on campus & & .743 & & \\
\hline $\begin{array}{l}\text { Ability to participate in intercollegiate } \\
\text { athletics }\end{array}$ & & .729 & & \\
\hline $\begin{array}{l}\text { The number of computers available } \\
\text { for students }\end{array}$ & & .721 & & \\
\hline Ability to transfer credits & & .548 & & \\
\hline The school is a private school & & .537 & & \\
\hline Financial Aid packages & & .534 & & \\
\hline Eight week class formats & & & .819 & \\
\hline The ability to schedule evening classes & & & .808 & \\
\hline $\begin{array}{l}\text { How quickly you can complete your } \\
\text { degree }\end{array}$ & & & .492 & \\
\hline $\begin{array}{l}\text { The location of the school is close to } \\
\text { your home }\end{array}$ & & & & .776 \\
\hline The ability to commute to campus & & & & .698 \\
\hline $\begin{array}{l}\text { The location of the school is close to } \\
\text { where you work }\end{array}$ & & & .466 & .661 \\
\hline Tuition Cost & & & & .555 \\
\hline
\end{tabular}

Extraction Method: Principal Component Analysis. Rotation Method: Varimax with Kaiser Normalization.

Analysis of variance was used to determine if there were differences in the mean scores on the four scales that were developed based on the dimensions of the factor analysis. Post hoc, paired comparison tests were conducted to determine exactly where differences existed. Tahmane's T square was used for the post hoc tests since the uneven group sizes could not guarantee the assumption of equal variances.

\section{RESULTS}

In Table 2 the means and standard deviations of the individual variables are presented. The top ten variables ranked by importance based on mean scores were (in descending order): The presence of a specific major you wanted to study (5.27); flexibility of the course offering (5.13) (tied) and accreditation of the school's programs (5.13); the ability to specialize inside your major field of study (4.99); the reputation of the University (4.89); tuition Cost (4.86); speed of degree completion (4.82); the ability to schedule evening classes (4.65); financial aid packages (4.54); and finally, the ability to commute to campus (4.47). There were three variables with overall means that indicated they were not important. They are (from the least important): The ability to participate in intercollegiate athletics (2.70); the school is private (2.71); and, the ability to live on campus (2.77). 
Table 3

Descriptive Statistics

\begin{tabular}{|c|c|c|c|}
\hline In Descending Order & $\mathbf{N}$ & Mean & Std. Deviation \\
\hline The presence of a specific major your wanted to study & 253 & 5.27 & 1.158 \\
\hline Flexibility of the course offerings & 255 & 5.13 & 1.044 \\
\hline Accreditation of the school's programs & 256 & 5.13 & 1.134 \\
\hline The ability to specialize inside your major field of study & 255 & 4.99 & 1.223 \\
\hline The reputation of the University & 256 & 4.89 & 1.042 \\
\hline Tuition Cost & 255 & 4.86 & 1.202 \\
\hline How quickly you can complete your degree & 256 & 4.82 & 1.256 \\
\hline The ability to schedule evening classes & 256 & 4.65 & 1.448 \\
\hline Financial Aid packages & 256 & 4.54 & 1.701 \\
\hline The ability to commute to campus & 255 & 4.52 & 1.518 \\
\hline The location of the school is close to your home & 255 & 4.47 & 1.377 \\
\hline Eight week class formats & 252 & 4.40 & 1.429 \\
\hline Ability to transfer credits & 256 & 4.12 & 1.631 \\
\hline The location of the school is close to where you work & 255 & 4.05 & 1.536 \\
\hline The number of computers available for students & 254 & 3.85 & 1.599 \\
\hline Access to internships & 253 & 3.60 & 1.969 \\
\hline The ability to live on campus & 253 & 2.77 & 1.979 \\
\hline The school is a private school & 253 & 2.71 & 1.437 \\
\hline Ability to participate in intercollegiate athletics & 256 & 2.70 & 1.724 \\
\hline Valid N & 235 & & \\
\hline
\end{tabular}

Table 4 presents the results of the Anova's to determine if differences exist in mean scores for the scales Academics, Campus Life, Speed/Convenience and Location/Cost based on the classification of student (traditional undergraduate, ACE or graduate.) As determined by the ANOVA there were no statistical differences in scores on the scale academics. There were statistical differences on all of the other scaled constructs: Campus Life, Speed/Convenience and Location/Cost.

Tamhane's T-square post hoc tests were used to identify where those differences exist. For the construct Campus Life, traditional undergraduate students' mean score was 31.74, graduate students' mean score was 22.37 and the ACE students' score was 23.24. The paired comparison tests indicate statistical differences existed between the graduate and traditional undergraduate students and the ACE and traditional undergraduate students. There were no differences between the graduate and the ACE students on this construct.

The construct Speed/Convenience also differed between the graduate and traditional undergraduate students and ACE and traditional undergraduate students. There were no differences between the graduate and the ACE student on this construct. The traditional undergraduate students' mean score was 12.15 , graduate students' mean score was 15.22 and the ACE students' score was 14.36.

For the construct Campus Life, traditional undergraduate students' mean score was 16.33, graduate students' mean score was 19.20 and the ACE students' score was 18.43. Again, statistical differences existed between the graduate and traditional undergraduate students and the ACE and traditional undergraduate students. Similar to the constructs of Campus life and Speed/Convenience there were no differences between the graduate and the ACE students on the construct Location/Cost. 
Table 4

ANOVA

\begin{tabular}{|l|l|c|c|c|c|c||}
\hline & & Sum of Squares & df & Mean Square & F & Sig. \\
\hline Academics & Between Groups & 79.709 & 2 & 39.855 & 1.836 & .162 \\
\hline & Within Groups & 5384.450 & 248 & 21.711 & & \\
\hline & Total & 5464.159 & 250 & & & \\
\hline & & & & & \\
\hline Campus Life & Between Groups & 4876.537 & 2 & 2438.268 & 46.175 & .000 \\
\hline & Within Groups & 12778.769 & 242 & 52.805 & & \\
\hline & Total & 17655.306 & 244 & & & \\
\hline & & & & & \\
\hline Speed / Convenience & Between Groups & 496.507 & 2 & 248.253 & 23.902 & .000 \\
\hline & Within Groups & 2586.172 & 249 & 10.386 & & \\
\hline & Total & 3082.679 & 251 & & & \\
\hline & & & & & \\
\hline & Between Groups & 435.065 & 2 & 217.533 & 13.388 & .000 \\
\hline & Within Groups & 4045.919 & 249 & 16.249 & & \\
\hline & Total & 4480.984 & 251 & & & \\
\hline
\end{tabular}

Tamhane Post Hoc Tests

\begin{tabular}{|l|c|c|c|c|}
\hline \multicolumn{1}{|c|}{ Variable } & $\begin{array}{c}\text { Traditional Student } \\
\text { Mean }\end{array}$ & $\begin{array}{c}\text { Graduate Student } \\
\text { Mean }\end{array}$ & $\begin{array}{c}\text { Ace Student } \\
\text { Mean }\end{array}$ & $\begin{array}{c}\text { Paired Significant Differences at the .05 } \\
\text { level }\end{array}$ \\
\hline Academics & 26.00 & 25.27 & 24.46 & None \\
\hline Campus Life & 31.74 & 22.37 & 23.24 & A, B \\
\hline & & & & 14.36 \\
\hline Speed / Convenience & 12.15 & 15.22 & & A, B \\
\hline Location / Cost & 16.33 & 19.20 & 18.43 & A, B \\
\hline
\end{tabular}

$\mathrm{A}=05$ Paired Comparision Difference Between Traditional Student and Graduate Student

B = Paired Comparision Difference Between Traditional Student and ACE Student

$\mathrm{C}=$ Paired Comparision Difference Between Graduate student and ACE Student

\section{IMPLICATIONS}

Based on the descriptive statistics, students come to this institution with a specific major in mind. This may indicate a predisposition to a career path. For the institution, clearly stating majors and the possible career options available on its web page and in its promotional material is very important.

The importance of flexibility of course offerings indicates the ability to design a course of study around a work schedule was important to this institution's students. The majority of the students worked in addition to attending school. Gone are the days when going to school is the students full-time job, now the majority work to cover the costs of attending college (Dundes and Marx 2006). Institutions with a student base similar to the one in the study need to provide flexibility in course times and offerings to accommodate working students. Related to this was ability to schedule evening classes which allow for full time "traditional" nine to five jobs.

Accreditations are considered very important. They were tied with flexibility as the second most important criteria. As for specialization within a major, as the prospective students become more savvy about the marketing of the institutions they are also becoming more adept at marketing themselves. Students may seek to differentiate 
themselves from others in the workplace through specialization. They are identifying niche job markets and prepare themselves for a smooth transition into these markets. The reputation of the school and its brand image helps to brand the students once they enter the marketplace.(here)

Common to high involvement consumer decision processes, pricing variables are important, evident by respondents' importance rating of the tuition and financial aid package items. By discounting price through financial aid the institution may alter the expected utility of the students'. Convenience, such as speed of degree completion and the ability to commute to campus were also important to the students. The development of satellite centers for class locations and online courses are other ways the institution may change the expected utility of students.

Turning the focus to the implications from the anova tables the lack of significant differences of the construct of "academics" is interesting. The five variables that comprised that construct were the top five attributes based on the mean importance ratings. For the most important constructs, the institution is facing a homogeneous market. Students want to be able to take courses offered in a flexible manner that allows specialization at a reputable, accredited institution. This allows for a commonality in marketing messages across all three classifications of students.

Since the institution in this study is a private school, it is unlikely to be able to compete with a class of competitors (public institutions) on the basis of price. For the marketing materials this translates to a focus, not on price, but on the benefits of the degree and reducing non-price costs which the can achieve through offering flexibility and convenience. By understanding the attributes different student populations desire the institution is better able to explain the benefits of the institution to potential students.

Paired comparison differences consistently existed between graduate and traditional undergraduate students, and the Ace and traditional undergraduate students. Indicating that age, not degree level of student, is an efficient segmentation variable for this institution. For this institution, "older" students' selection criteria are different from the younger traditional students and that graduate and ace students can be treated as a homogeneous market along these attributes. This facilitates more efficient media buying and message development to target the adult undergraduate and graduate students since they are similar.

From a message development perspective, instead of three separate messages, there can be one overriding theme, the "Academics" construct and two sub-themes-- one for younger traditional students and one for the ACE and graduate students. The overlap of messages will increase efficiency in delivery of information to prospective students.

To determine student satisfaction, examining the school's performance on the selection criteria is recommended. Aggregating students across classifications on an importance/performance grid will yield misleading results. An importance-performance grid based on age categories covering Academics, Campus life, Speed/Convenience and Location/Cost may be useful to college administrators trying to assess the institutions performance on those factors students regard as important.

\section{LIMITATIONS}

The major limitation of this study is the sample population. The sample was comprised of new students to the institution and does not include students who did not choose to attend. This study is not able to compare the importance ratings of attributes for students deciding to attend the institution with those students who decided to attend elsewhere. This study provides a glimpse of the importance of the selection criteria of students who have chosen this particular institution.

\section{CONCLUSION}

Across the United States, institutions of higher learning face stiffer competition for students. Anecdotal evidence suggests many institutions are adopting a more traditional marketing mindset in order to successfully 
manage their enrollment. Of importance in this greater marketing focus is for college and university administrators to understand criteria important to prospective students when those students are deciding which institution to attend. Knowledge of these selection criteria, and how they may differ across student types, will allow a college or university to better manage its marketing effort for maximum efficiency.

This paper examined the importance of certain selection criteria to traditional undergraduate, graduate and adult and continuing education students at a specific university. The results indicate that a more targeted approach by this university's administration, when it markets to prospective student types, should prove more effective. For instance, marketing messages targeted toward graduate and ACE students should focus on the speed of degree completion, the cost, and the location of the university's campus. For traditional undergraduate students, the university administration should focus on student life and other attributes related to campus life. If the university enters into a general brand awareness campaign, the focus should be on academic attributes as that set of criteria was important to all respondents.

Future research on this topic should examine the differences of selection attribute importance between institutions of different sizes, affiliations (public vs. private) and perhaps primary course delivery (traditional classroom meeting vs. an online format). Researchers examining this topic further may also want to explore the relationship between selection criteria, student satisfaction, retention and alumni giving - all important elements to an institution's overall health.

\section{AUTHOR INFORMATION}

Dr. Kurt Schimmel is the Associate Dean of the School of Business, he has a Doctor of Business Administration with a major concentration in marketing. He is the author of over 35 peer review research publications. His current research interests include: e-commerce, consumer decision making and services marketing and management.

Gayle J. Marco received her Ph.D. degree (Major: Marketing Education and Vocational Education) from University of Pittsburgh in 1984. Her research interest includes various areas of consumer decision making and buyer behavior. She has consulted for various companies in the Pittsburgh area. The consulting areas include product repositioning, market development for new products, needs assessments, and market plan development. She has published in Journal of Global Business and The Journal of American Academy of Business as well as numerous conference proceedings.

Mark Eschenfelder is an associate professor of economics at Robert Morris University. He received his Ph.D. in Economics from the University of Missouri. His research focus is on economics education. He is co-director of the Annual Teaching Economics Conference and of the Center for Economic Education at Robert Morris University. The Center for Economic Education at Robert Morris University is affiliated with the National Council on Economic Education and Economics Pennsylvania. The Center promotes K-12 economic education in the local community. He is a co-author of a textbook on the Economics of Sports. Mark is active in the Pennsylvania Economic Association and is a past president.

Stanko Racic is presently Assistant Professor of Finance at Robert Morris University' School of Business, located in Pittsburgh, PA. He holds PhD in Finance from University of Pittsburgh's Katz Graduate School of Business. His work was presented and published in proceedings of several academic conferences and published in Journal of Financial Economics and Journal of Business and Behavioral Science. Among rewards and recognitions that he received while a Ph.D. student Katz School of Business, is Distinguish Professor Award from the 1999 Executive MBA class.

\section{REFERENCES}

1. Brookes, Mari (2003) Higher Education: Marketing in a quasi-commercial service industry. International Journal of Nonprofit and Voluntary Sector Marketing 8 (2) 134-142.

2. Chapman, Randall G. (1986) Toward a Theory of College Selection: A model of college search and choice behavior, in Richard H Lutz ed., Advances in Consumer Research vol 13 Provo, Utah. 
3. Donaldson, Bill, Carolyn McNicholas (2004) Understanding the postgraduate education markt for UK based students: A review and empirical study. International Journal of Nonprofit and Voluntary Sector Marketing 9 (4) 346-361.

4. Dundes, Lauren and Jeff Marx (2006) Balancing work and academics in college: why do students working 10 to 19 hours a week excel? Journal of College Student Retention 8 (1) 107-121.

5. Hooley, G.J. and Lynch J.E. (1981) Modeling the student university choice process through the use of conjoint measurement techniques. European Research 9 (4) 158-170.

6. Hoverstad, Ronald, Charles Lamb, and Patrick Miller (1989) College benefit segmentation analysis: Approach and results, in Advances in Consumer Research vol 16 332-338.

7. Ivy, Jonathan (2001) Higher education institution image: A correspondence analysis approach. The International Journal of Educational Management 15 (6/7) 276-282.

8. Judson, Kimberly M., Jeffery D. James, \& Timothy W. Aurand (2004) "Marketing the University to Student athletes: Understanding University Selection Criteria." Journal of Marketing for Higher Education 14 (1) 23-40.

9. Krampf, R.F. and A.C. Heinlein (1981) Developing marketing strategies and tactics in higher education through target market research. Decision Sciences 12 (2) 175-193.

10. Kirp David (2003) Shakespeare, Einstein, and the bottom line: The marketing of higher education. Cambridge, MA: Harvard University Press.

11. Moogan, Yvonne, Steve Baron, Steve Bainbridge (2001) Timings and trade-offs in the marketing of higher education courses: A conjoint approach. Marketing Intelligence and Planning 19 (3) 179-187.

12. Price, If, Fides Matzdorf, Louise Smith, Helen Agahi (2003) "The impact of facilities on student choice of university." Facilities 21 (10) 212-222.

13. Soutar, Geoffrey \& Julia turner, (2002) Students' preferences for university: A conjoint analysis. The International Journal of Educational Management 16 (1) 40-45.

14. Tapp, Alan, Keith Hicks, Merlin Stone (2004) Direct and database marketing and customer relationship management in recruiting students for higher education. International Journal of Nonprofit and Voluntary Sector Marketing 9 (4) 335-346. 
NOTES 